\title{
Indicators of the impact of climate change on migratory species
}

\author{
Stuart E. Newson ${ }^{1, *}$, Sonia Mendes ${ }^{2}$, Humphrey Q. P. Crick ${ }^{1}$, Nicholas K. Dulvy ${ }^{3}$, \\ Jon D. R. Houghton ${ }^{4}$, Graeme C. Hays ${ }^{4}$, Anthony M. Hutson ${ }^{5}$, Colin D. MacLeod ${ }^{2}$, \\ Graham J. Pierce ${ }^{2}$, Robert A. Robinson ${ }^{1}$ \\ ${ }^{1}$ British Trust for Ornithology, The Nunnery, Thetford IP24 2PU, UK \\ ${ }^{2}$ School of Biological Sciences, Zoology Building, Tillydrone, University of Aberdeen, Aberdeen AB24 2TZ, UK \\ ${ }^{3}$ The Centre for Environment, Fisheries and Aquaculture Science, Lowestoft Laboratory, Pakefield Road, Lowestoft NR33 0HT, \\ UK and Simon Fraser University, Biological Sciences, Burnaby, Victoria V5A 1S6, Canada \\ ${ }^{4}$ Department of Biological Sciences, Swansea University, Swansea SA2 8PP, UK \\ ${ }^{5}$ Winkfield, Station Road, Plumpton Green BN7 3BU, UK
}

\begin{abstract}
The Bonn Convention on the Conservation of Migratory Species of Wild Animals adopted a Resolution in 2005 recognising the impacts of climate change on migratory species. It called on Contracting Parties to undertake more research to improve our understanding of these impacts and to implement adaptation measures to reduce foreseeable adverse effects. Given the large diversity of taxa and species affected by climate change, it is impossible to monitor all species and effects thereof. However, it is likely that many of the key ecological and physical processes through which climate change may impact wildlife could be monitored using a suite of indicators, each comprising parameters of species/populations or groups of species as proxies for wider assemblages, habitats and ecosystems. Herein, we identify a suite of 17 indicators whose attributes could reveal negative impacts of climate change on the global status of migratory species: 4 for birds, 4 for marine mammals, 2 for sea turtles, 1 for fish, 3 for land mammals and 3 for bats. A few of these indicators would be relatively straightforward to develop, but most would require additional data collation, and in many cases methodological development. Choosing and developing indicators of the impacts of climate change on migratory species is a challenge, particularly with endangered species, which are subject to many other pressures. To identify and implement conservation measures for these species, indicators must account for the full ensemble of pressures, and link to a system of alerts and triggers for action.
\end{abstract}

KEY WORDS: Conservation · Management · Birds · Fish · Mammals · Turtles · Bats · Climate change $\cdot$ Migration

Resale or republication not permitted without written consent of the publisher

\section{INTRODUCTION}

Anthropogenically induced climate change is one of the major factors likely to affect the Earth's ecosystems in the coming years and centuries (IPCC 2007, Stern 2007). The role of human activities in the observed changes is unequivocal. Migratory species, by travelling large distances, often between discrete sites, are particularly likely to be affected by climate change at some point in their life cycles, and there is already compelling evidence for impacts (negative, positive or neutral) on a wide range of birds, marine mammals, fish, sea turtles, squid, bats, terrestrial mammals and insects (reviewed in Learmonth et al. 2006, Robinson et al. 2009). Impacts of climatic variation-and by implication, of directional climate change-include changes in timing of migration (e.g. Sims et al. 2001, Lehikoinen et al. 2004), changes in population sizes (e.g. Crick 1999, Pierce \& Boyle 2003), and changes in population distributions (e.g. Berry et al. 2001, Zheng 
et al. 2001, Austin \& Rehfisch 2005, MacLeod et al. 2005, Sparks et al. 2007).

While there are a large number of physical measures of climate change, there are few indicators of the biological consequences of climate change. The Bonn Convention on the Conservation of Migratory Species of Wild Animals (CMS 1979, www.cms.int) adopted a Resolution (CoP 8.13) in 2005 recognising the impacts of climate change on migratory species and advised that more research is needed to improve our understanding of these impacts and to implement adaptation measures to help reduce foreseeable adverse effects. In order to achieve this successfully, monitoring of the impacts is required, both to quantify the extent of the problem, but also to assess the success of any implemented measures. Clearly, given the great range and diversity of taxa affected by climate change, it is impractical to monitor all species and all pathways of climate change. However, it is likely that many of the key physical and ecological processes through which climate change may impact wildlife could be monitored through a suite of key indicators, each comprising of certain parameters of species/populations or of groups of species as proxies for wider assemblages, habitats and ecosystems.

Indicators quantify and summarise complex phenomena and are increasingly used as a decision-support tool within management frameworks of complex systems (e.g. Rice \& Rochet 2005). Indicators can have a number of uses but are typically used to communicate the state of a species or habitat, the human pressures on the environment and the response of management to prevent or mitigate the issues. For example, an indicator of the state of bird populations co-developed by the British Trust for Ornithology (BTO) and Royal Society for the Protection of Birds (RSPB) has been adopted as one of the UK Government Sustainable Development Framework Indica-

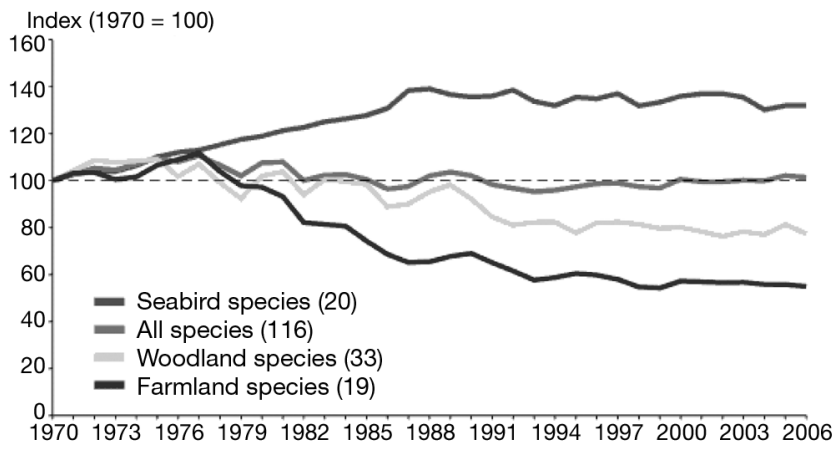

Fig. 1. Indicator for wild birds in the UK 1970 to 2006. One of 5 headline biodiversity indicators used by the UK government to assess progress in sustaining biodiversity. This provides an annually updated index of abundance of 3 different groups of bird species measured relative to their abundance in 1970 . Values in parentheses show the number of species included in each category. Source: Defra, RSPB, BTO tors (Fig. 1). This indicator was developed to monitor and highlight the declining conservation status of farmland birds, stimulating government action to address this by altering agri-environment scheme designs (Gregory et al. 2004). In the marine environment, fisheries management in the European Union has broadened from the traditional, narrow focus on single-species management to a wider ecosystem-based approach, for which an array of indicators have been developed. These describe the depleted status of fish stocks, the average size of fish, the sustainability of fisheries and climate change effects on fish assemblages (Pauly \& Watson 2005, Harrison 2006, Dulvy et al. 2008).

The aim of this work was to identify a suite of indicators with suitable properties to measure negative climate change impacts on the global status of migratory species, through a process of expert consultation and review. Ideally this suite of indicators would be representative of the widest possible range of taxa, habitats and geographical regions as well as of the key physical and ecological processes through which climate change is expected to affect migratory species. However, the choice of indicators inevitably reflects to some degree the knowledge of the experts who have contributed to this selection, and their understanding of climate change impacts.

\section{MATERIALS AND METHODS}

Desirable properties of an indicator. Indicators can have a far-reaching impact on the policies of conservation, on socio-economic factors and on the species or ecosystems we are trying to conserve. Therefore a careful choice of indicators is needed. A key problem when developing a suite of indicators is that there may be hundreds of plausible candidate indicators (Rice 2003). Potential indicators need to be evaluated for the degree to which they are 'fit-for-purpose' as a decision-support tool. As a guide, we defined desirable criteria for evaluating and choosing indicators according to the literature (e.g. Rice \& Rochet 2005), and adapted these to fulfill the specific objectives of this work. In total, 12 criteria for desirable indicators were proposed (Table 1). These address 4 key aspects of the indicator: net impact, statistical properties, data requirements and global applicability of data collection methods.

Choosing the indicator suite. Guided by the literature, expert opinion and reference to the desirable properties listed in Table 1, a suite of indicators that reflected the negative impacts of climate change on key groups of migratory species was selected from a larger list presented at a workshop attended by international experts in this field. The focus on 'negative impacts', defined here as a negative effect on the conservation 
status of the population or community of interest, was specified in order to inform Contracting Parties to the CMS of detrimental impacts of climate change that may require policy action, although it is acknowledged that impacts of climate change may be beneficial or neutral for some species groups. Importantly, phenological changes or changes in distribution would not necessarily be classed as 'negative impacts'. Whilst these may exhibit a strong link to climate, and can have important management implications at a regional level, in most cases there is currently little evidence that these would negatively impact on the conservation status of the species or communities of interest as a whole. Examples include phenological indicators for wild birds, e.g. earlier egg-laying (Crick \& Sparks 1999, Both \& Visser 2001) and earlier arrival on breeding grounds (Lehikoinen et al. 2004), changes in shorebird distribution (Maclean et al. 2008) and range shifts in fish (Perry et al. 2005) and marine mammals (MacLeod et al. 2005). Migratory species were defined here, according to the CMS, as 'species that cyclically and predictably cross one or more national jurisdictional boundaries'. Although species listed in CMS Appendices 1 or 2 (migratory species of conservation concern) were the main focus of the selection process, we did not restrict indicators to these species alone. This was because these Appendices are regularly updated and there are additional species that are potential candidates for listing, and because there are some migratory species, not listed, that have economic or iconic importance.

\section{RESULTS}

We selected a suite of 17 indicators for further consideration (Table 2): 4 for birds, 4 for marine mammals, 1 for fish, 2 for sea turtles, 3 for land mammals and 3 for bats (examples shown in Fig. 2). The statistical properties and availability of data for producing each indicator are summarised in Table 2 . This suite reflects a subset of a much larger list of indicators originally considered. For a full discussion of all indicators considered in relation to the criteria listed in Table 1 , see Newson et al. (2008).

Table 1. Criteria for evaluating impact of climate change indicators for migratory species

\footnotetext{
Impact, policy relevance, public perception and communication

Net impact: To what degree does the indicator measure net impact (negative impact of most interest here) of climate change on populations either regionally or globally?

Easy to understand: The indicator must be understandable for non-scientists and decision makers.

Policy relevance: What is the degree of policy-relevance to the Convention of Migratory Species (CMS), i.e. are the species listed on the CMS Appendices, those of its daughter agreements or other legislation or agreements (national, regional or international)?

Public profile: How high would the public profile of the indicator be?
}

\section{Statistical properties of the indicator}

Specificity: To what degree is the indicator specific to climate change as a single pressure or affected by a number of other pressures (exploitation, pollution, invasive species etc.)?

Sensitivity: To what degree is the indicator sensitive to climate change, i.e. is the slope of the relationship between a measure of climate change versus indicator response shallow or steep?

Responsiveness: Is there a lag in indicator responsiveness after a change in pressure (climate change)? If so, how long is the $\operatorname{lag}$ (years, decades)?

Theoretical basis: What is the strength of theoretical basis underlying the indicator, i.e. is the indicator based on an existing body of theory, empirical or time series of data that allow a realistic setting of objectives?

\section{Data requirements}

Data availability: How available are the data? Are data to support the indicator readily available or available at a reasonable cost/benefit ratio?

Data quality: What is the quality of the data? Are the data collected (or have the potential to be collected) through a welldesigned monitoring program and/or likely to be of high quality?

Applicability of data collection methods

Applicability: How widely applicable are the data collection methods? Are the data collection methods readily applicable and a monitoring scheme feasible in less developed countries?

Continuity of the data collection scheme: What is the long-term continuity of the data collection scheme? 


\section{Birds}

Indicator 1: Change in relative abundance of trans-

Saharan migrant birds on their breeding grounds

There is evidence that reduced precipitation and increasing temperature is leading to loss of stop-over and wintering habitat for trans-Saharan migrant birds (e.g. Sanderson et al. 2006), with resulting impacts on demography (e.g. increased mortality) and subsequent declines in abundance. Differential changes in the timing of arrival and breeding with respect to food supplies may be important too, leading to reductions in productivity and abundance. This indicator would re- present a negative impact of climate change on the population status of trans-Saharan migrant birds.

Indicator 2: Change in the number of breeding pairs of Antarctic penguins

Changes in prey availability as a result of climate change are thought to have important consequences for some penguin species and other species inhabiting Antarctica and sub-Antarctic islands, which cannot move their breeding sites as foraging conditions change. In particular, krill Euphausia superba availability is associated with pack-ice cover, which is pre-

Table 2. Statistical properties and comparative effort needed to develop the indicator suite. The statistical properties and representativeness are scored low (1) to high (3), whilst (?) denotes that the indicator is not understood well enough to provide a score. Time-series available (T): underlying data collected according to standardised monitoring protocol, and constructing an indicator from these data would be feasible. Empirical observation (E): data are collected according to a standardised monitoring protocol, but there are currently significant gaps in coverage at the species or geographical level. In addition, it is likely that some development work would be needed to construct an appropriate indicator. Concept-only (C): good theoretical basis for nature of the climate impact, but the data are not currently collected according to a standardised monitoring protocol; there are perhaps gaps in coverage, and it is likely that significant development work would be needed to produce the indicator. Statistical and other properties: I = specificity, II = sensitivity, III = responsiveness, IV $=$ theoretical basis, V = taxonomic representativeness and VI = public profile. CMS: Conservation of Migratory Species

\begin{tabular}{|c|c|c|c|c|c|c|c|c|c|c|c|}
\hline \multirow{2}{*}{$\begin{array}{l}\text { Indicator } \\
\text { Birds }\end{array}$} & \multirow[t]{2}{*}{$\begin{array}{l}\text { Geographical } \\
\text { scope }\end{array}$} & \multirow[t]{2}{*}{$\begin{array}{l}\text { Broad } \\
\text { habitat }\end{array}$} & \multirow[t]{2}{*}{$\begin{array}{l}\text { Effort to } \\
\text { develop } \\
\text { indicator }\end{array}$} & \multirow[t]{2}{*}{$\begin{array}{l}\text { CMS } \\
\text { listed }\end{array}$} & & $\begin{array}{l}\text { ica } \\
\text { II }\end{array}$ & or & pro & pe & $\mathrm{rti}$ & $\begin{array}{l}\text { es } \\
\text { II }\end{array}$ \\
\hline & & & & & & & & & & & \\
\hline $\begin{array}{l}\text { Relative abundance of trans- } \\
\text { Saharan migrant birds }\end{array}$ & Europe \& Africa & Arid-dry & $\mathrm{T}$ & Yes & 2 & 3 & 3 & 3 & 1 & & 3 \\
\hline $\begin{array}{l}\text { Change in the number of } \\
\text { breeding pairs of penguins }\end{array}$ & Southern Ocean & Marine/coastal & E & No & 3 & 1 & 2 & 2 & 3 & & 3 \\
\hline $\begin{array}{l}\text { Change in reproductive output } \\
\text { of fish-eating seabirds }\end{array}$ & Atlantic \& Arctic Oceans & Marine/coastal & E & Yes & 2 & 3 & 3 & 3 & 2 & & 3 \\
\hline $\begin{array}{l}\text { Change in reproductive output } \\
\text { of shorebirds }\end{array}$ & Europe \& North America & Tundra & E & Yes & 3 & 2 & 3 & 2 & 3 & & 1 \\
\hline Marine mammals & & & & & & & & & & & \\
\hline $\begin{array}{l}\text { Body condition of polar bears } \\
\text { and in cub survival }\end{array}$ & North America & Marine/coastal & $\mathrm{T}$ & No & 2 & 2 & 3 & 3 & 1 & & 3 \\
\hline Antarctic fur seal pup production & Southern Ocean & Marine/coastal & $\mathrm{T}$ & No & 2 & 3 & 3 & 2 & 3 & & 3 \\
\hline Southern right whale calf production A & Atlantic \& Southern Oceans & Marine/coastal & $\mathrm{T} / \mathrm{E}$ & Yes & 2 & 3 & 3 & 2 & 2 & & 3 \\
\hline Ice-breeding seal pup survival & North America \& Europe & Marine/coastal & $\mathrm{C}$ & No & 2 & 3 & 3 & 2 & 3 & & 3 \\
\hline Fish & & & & & & & & & & & \\
\hline Chinook salmon juvenile survival & North America & Freshwater & $\mathrm{C}$ & No & 2 & 3 & 3 & 2 & 1 & & 2 \\
\hline Turtles & & & & & & & & & & & \\
\hline $\begin{array}{l}\text { Changing sea turtle nesting } \\
\text { habitat due to sea-level rise }\end{array}$ & Pacific \& Indian Oceans & Marine/coastal & $\mathrm{C}$ & Yes & 3 & 3 & 3 & 2 & 2 & & 3 \\
\hline Sea turtle sex ratios & Pacific \& Indian Oceans & Marine/coastal & E & Yes & 3 & 3 & 3 & 3 & 2 & & 3 \\
\hline Terrestrial mammals & & & & & & & & & & & \\
\hline $\begin{array}{l}\text { Caribou/reindeer calf production } \\
\text { and survival }\end{array}$ & North America \& Europe & Tundra & $\mathrm{E}$ & No & 2 & 1 & 3 & 1 & 1 & & 3 \\
\hline $\begin{array}{l}\text { Population size and range of } \\
\text { large herbivorous mammals }\end{array}$ & Africa & Arid-dry & $\mathrm{C}$ & Yes & 2 & 3 & 2 & 1 & 3 & & 3 \\
\hline Population size of saiga antelope & Asia & Arid-dry & $\mathrm{C}$ & Yes & 2 & 3 & 3 & 1 & 1 & & 1 \\
\hline Bats & & & & & & & & & & & \\
\hline $\begin{array}{l}\text { Abundance of bats at 'underground' } \\
\text { hibernation sites }\end{array}$ & Europe & Montane & $\mathrm{C}$ & Yes & 1 & $?$ & $?$ & ? & ? & & ? \\
\hline Populations of straw-coloured fruit bat & Africa & Arid-dry & $\mathrm{C}$ & Yes & 1 & $?$ & $?$ & ? & ? & & ? \\
\hline Populations of Mexican free-tailed bats & South America & Arid-dry & $\mathrm{C}$ & Yes & 1 & $?$ & ? & ? & $?$ & & ? \\
\hline
\end{tabular}



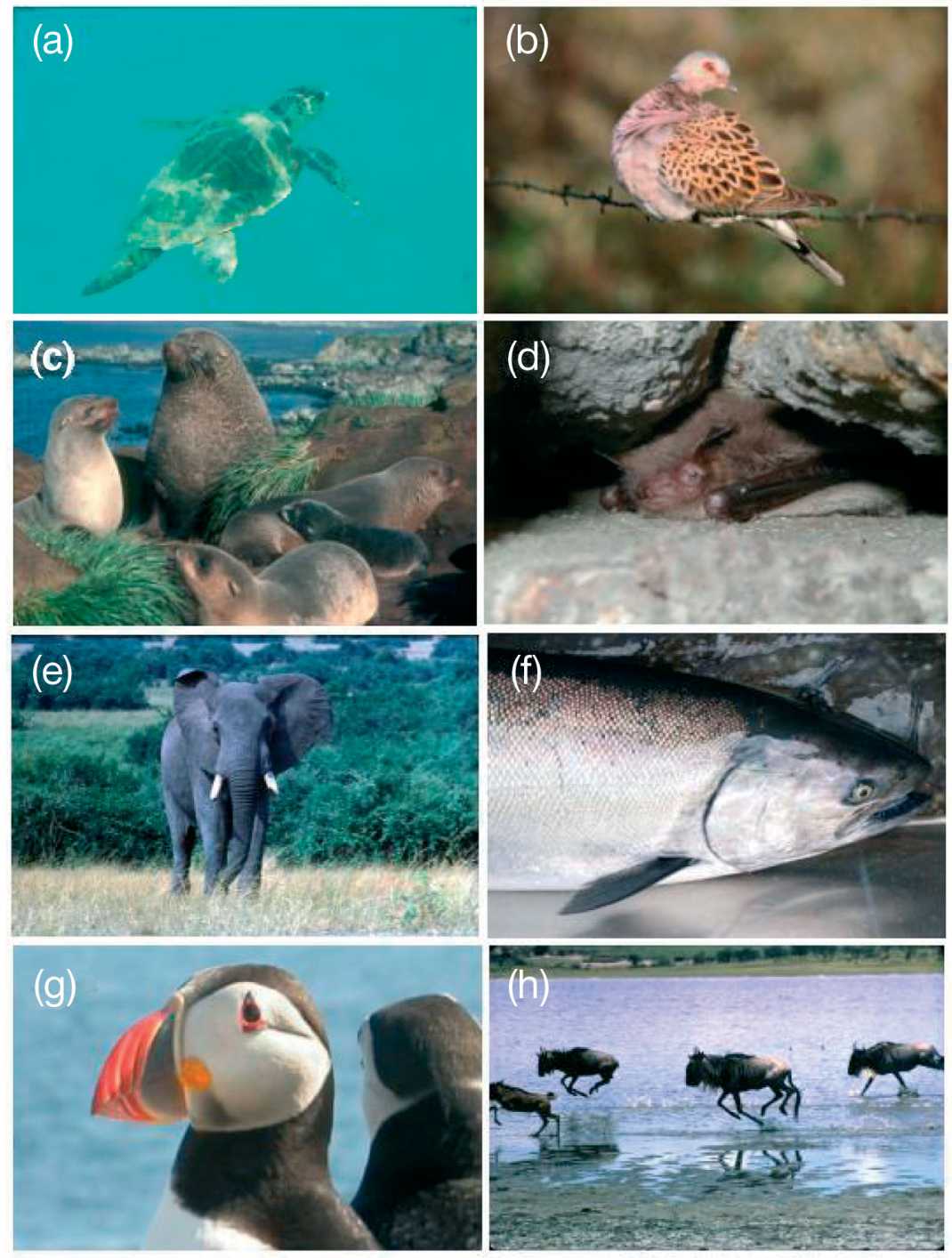

Fig. 2. Examples of migratory indicator species/species groups likely to impacted by climate change. (a) Sea turtles such as the loggerhead turtle Caretta caretta may be threatened by rising sea levels causing loss of nesting habitat and increasing incubation temperatures leading to only female hatchlings; (b) reduced precipitation and increasing temperature may lead to a loss of stop-over and wintering habitat for trans-Saharan migrant birds such as the turtle dove Streptopelia turtur; (c) a reduction in the number of pups of Antarctic fur seal Arctocephalus gazella has been linked to a change in prey availability as a result of rising sea temperatures; (d) changes in temperature may influence the species composition and hibernation behaviour of bats such as this Daubenton's bat Myotis daubentonii which uses 'underground' hibernation sites, with potential impacts on productivity and survival; (e) elephants Loxodonta africana and several other species of large herbivorous African mammals may be threatened by reduced precipitation; (f) juvenile survival of spring-summer chinook salmon Oncorhynchus tshawytscha is strongly related to water temperature, which is predicted to increase with climate change; $(\mathrm{g})$ there is good evidence for a relationship between climate change, prey populations and reproductive output of seabird populations such as the Atlantic puffin Fratercula arctica in the North-East Atlantic, Arctic and North Seas; (h) reduced precipitation is likely to influence the distribution and survival of wildebeest Connochnetes taurinus. Reproduced, with permission, from G. Hays (a), M. Weston (b), C. Duck (c), J. Altringham/Bat Conservation Trust (d), P. Lack (e,h), D. Braun (f) and S. Newson (g) dicted to shrink with increasing temperatures (Trathan et al. 2003). This in turn would reduce productivity and survival of penguins (e.g. Wilson et al. 2001, Croxall et al. 2002, Reid et al. 2005). There is evidence that this indicator would represent a negative impact of climate change on the population status of penguins in parts of Antarctica (e.g. Croxall et al. 2002) and is likely to be a good indicator of climate change impacts for other krilleating species. This indicator would focus on penguin population size (specifically number of breeding pairs), which unlike many other seabirds of the Antarctic are not influenced by long-line fishing activities, and therefore with a high specificity in terms of its link with climate change.

Indicator 3: Change in reproductive output (chicks fledged per breeding attempt) of fish-eating seabird populations

There is good evidence for a relationship between climate change, prey availability and reproductive output of seabird populations in the North-East Atlantic, Arctic and North Seas (e.g. Harris \& Wanless 1990, Frederiksen et al. 2007). When considering the geographic and taxonomic scope of this indicator, it was argued that albatross and related species should be excluded because of the difficulty in distinguishing the negative impacts of long-line fishing on bycatch of these species from impacts of climate change. This indicator would reflect a negative impact of climate change on the population status of seabird populations.

\section{Indicator 4: Change in reproductive} output of Arctic shorebirds

There is evidence that climate-driven timing of snow-melt and insect emergence has changed the availability of shorebird prey in recent years (Tulp \& Schekkerman 2008). Warmer 
summers are likely to increase productivity through both increased invertebrate abundance and reduced mortality from chilling (Schekkerman et al. 1998). However, in years of highest temperatures, declines in productivity have been observed (Beale et al. 2006). Whilst the mechanism underlying this decline is not known, it is predicted that further rises in temperature will reduce productivity in the long-term. For example, as habitats become restricted with warming and habitat succession, this may affect productivity through decreased breeding success and proportion of birds breeding. This indicator would be based on annual variability in productivity through estimation of juvenile:adult ratios (e.g. Schekkerman et al. 1998, Clark et al. 2004, Beale et al. 2006).

\section{Marine mammals}

Indicator 5: Annual trends in body condition of polar bears and in cub survival in the Western Hudson Bay and Southern Beaufort Sea

Body condition and cub survival of polar bears Ursus maritimus in the Western Hudson Bay (WHB) and Southern Beaufort Sea (SBS) have declined with the increase in spring temperatures and the break-up of sea ice over the past 15 to $20 \mathrm{yr}$ as a result of climatic variation and climate change (Stirling et al. 1999, Regehr et al. 2006, Rode et al. 2007). It is hypothesised that earlier ice break-up results in poorer conditions of polar bears because they have less time to feed on icebreeding seals, their primary prey. Reduced foraging opportunities for adult females as a result of the earlier ice break-up result in poorer survival of cubs (Stirling et al. 1999, Regehr et al. 2007a,b, Rode et al. 2007). This polar bear is a charismatic, migratory species with high public perception and profile and has an IUCN status of 'vulnerable' to extinction.

\section{Indicator 6: Antarctic fur seal pup production}

The population of Antarctic fur seals Arctocephalus gazella on Bird Island, South Georgia, has shown dramatic reductions in pup production in years immediately following extreme positive austral summer sea surface temperature (SST) anomalies (Forcada et al. 2005). A 10 yr period of persistent high SST, driven by global climatic variability (El Niño Southern Oscillation, ENSO), over and above what has occurred in the past, and subsequent positive SST anomalies in South Georgia could explain the reductions in pup production. A potential causal mechanism for this is the effect of warmer oceanographic conditions on availability of krill, the primary prey of fur seals (Reid \& Arnould 1996, Trathan et al. 2003, Murphy et al. 2007). Female fur seals are central place foragers during lactation and rearing of their young. Nursing females are almost totally dependent on krill availability for food (Reid \& Arnould 1996), and years of low krill adversely affect seal breeding success. The link between these climatic and oceanographic indices and climate change is not clear. Nevertheless, correlations suggest that this indicator would be sensitive to persistent sea surface temperature warming (Forcada et al. 2005). This indicator would illustrate the effects of climate change on the southern ocean ecosystem and would be an early warning sign of population-level consequences for fur seals. Pup production has been closely linked to maternal condition in many otariid seal species, indirectly reflecting prey availability to females (Guinet et al. 1994, Soto et al. 2004, Forcada et al. 2005, Lea et al. 2006); therefore this indicator could be representative of the key ecological process through which climate change may impact on these species.

Indicator 7: Southern right whale calf production in the Antarctic

Correlations have been found between southern right whale Eubalaena australis calving output index and SST anomalies both in the feeding grounds and in the El Niño regions of the Pacific (Cooke et al. 2003, Leaper et al. 2006). The possible explanation for this relationship is that krill availability in the summer feeding grounds (Trathan \& Murphy 2002, Trathan et al. 2003) before conception of whale calves affects the reproductive success during the following winter. The link between these climatic and oceanographic indices and climate change is not clear, as there is debate on whether the frequency or strength of ENSO events will alter with climate change (Timmerman et al. 1999, Moy et al. 2002). Nevertheless, the correlations found suggest that this indicator would be sensitive to any potential regional changes in SST caused by climate change. A correlation has also been shown between the calving rate of the northern right whale, the abundance of their prey and the North Atlantic Oscillation (NAO) (Greene \& Pershing 2004). Of the 3 extant right whale species, the southern right whale is the only species for which there is a sufficiently large population size for it to be a viable indicator. Right whales are the most threatened of the baleen whales, and are redlisted as 'threatened' by the World Conservation Union (IUCN). This indicator would illustrate the effects of climate change on the Southern Ocean ecosystem and be an early warning sign of population-level consequences to southern right whales. 
Indicator 8: Ice-breeding seal pup survival

Climate change is expected to cause a major reduction in sea-ice and snow cover (IPCC 2007). In the Arctic, Baltic and Caspian seas, early sea-ice break-up or snow melts are likely to reduce the extent of breeding habitat for ice-breeding seals (Smith \& Harwood 2001). In the absence of good ice/snow conditions, pups become more vulnerable to adverse weather conditions, starvation and predation, resulting in high mortality (Smith \& Harwood 2001, Ferguson et al. 2005). Populations of ringed seals Phoca hispida in some areas are showing downward trends in reproductive rates and survival of young (Stirling 2005). It is thought that these trends are linked to changes in sea-ice conditions and other major ecosystem shifts (Stirling 2005). In the Western Hudson Bay, a significant reduction in ringed seal recruitment during the period 1990 to 2001 has been attributed to climate warming (Ferguson et al. 2005). In the southern Baltic Sea, a series of nearly ice-free winters from 1989 to 1995 led to high pup mortalities (Härkönen et al. 1998). A similar impact is predicted for Caspian seals Phoca caspica. This indicator would illustrate the effects of climate change on migratory species that depend on ice for breeding.

\section{Fish}

Indicator 9: Chinook salmon juvenile survival

Catches of different salmon species, timing of migration in returning salmon, and both juvenile and adult salmon survival have shown to be related to climate variability and change in several parts of the world (Hare \& Francis 1994, Mantua et al. 1997, Mueter et al. 2002, Beaugrand \& Reid 2003, Hyatt et al. 2003, Crozier \& Zabel 2006). Juvenile survival of springsummer chinook salmon Oncorhynchus tshawytscha has been shown to be negatively correlated with water temperature in wide and warm streams and positively correlated with stream flow in narrow cool streams, in the Salmon River basin, Idaho, USA (Crozier \& Zabel 2006). Stream temperatures in the Salmon River basin already routinely exceed the $13^{\circ} \mathrm{C}$ maximum daily temperature thresholds for salmonids (Donato 2002). Annual air temperatures have also been increasing steadily since 1992 (Crozier \& Zabel 2006). The effects of climate change on juvenile survival in salmon populations are likely to be broadly representative of the effects on other anadromous species, such as sturgeons.

\section{Sea turtles}

Indicator 10: Changing sea turtle nesting habitat due to sea-level rise

Sea turtles will be affected by an increase in sea levels through the loss of egg-laying beaches (Fish et al. 2005). The construction of sea wall defences and protective measures for coastal habitats against increasing sea levels, as well as changes in the development and use of coastal areas, will directly affect egg-laying beaches. Alternatively, at other less developed sites, the dynamic nature of beaches may simply lead to these gradually moving inland (Fish et al. 2005). However, in the Pacific and Indian Oceans and Caribbean Sea where nesting frequently takes place on low lying coralline islands, the situation may be far worse for sea turtles, with complete loss of suitable nesting habitat. Under a predicted sea-level rise of $0.5 \mathrm{~m}$, GIS-based elevation models have indicated that up to $32 \%$ of the beaches used by nesting sea turtles in the Caribbean could be lost via 'coastal squeeze' - the loss of coastal habitat between the high-water mark and hard coastal defences, such as sea-walls (Hays 2008). Several Pacific States are currently threatened with total disappearance and 2 uninhabited islands in the Kiribati chain have already disappeared through sea level rise (Fish et al. 2005, IPCC 2007).

\section{Indicator 11: Skewed sex ratios in sea turtles}

For sea turtles, an even sex ratio of hatchlings is produced within clutches at $\sim 29^{\circ} \mathrm{C}$ (known as the pivotal temperature), above which the ratio is skewed towards female production (Hays et al. 2003). Climate-induced warming at nesting beaches may lead to the production of only female hatchlings, with likely population consequences (Godfrey et al. 1996, Hays et al. 2003, Hawkes et al. 2007, Houghton et al. 2007). Quantitative genetic analyses and behavioural data suggest that populations with temperature-dependent sex determination may be unable to evolve rapidly enough to counteract the negative fitness consequences of rapid global temperature change (Hays 2008). Indeed, pivotal temperatures for sea turtles appear highly conserved, always being close to $29^{\circ} \mathrm{C}$, across a range of species and populations (Hays 2008). Consequently, shifts in beach temperature do not need to be large for sex ratio shifts to manifest themselves at a population level. Increased sand temperatures have already been reported for important nesting sites such as Ascension Island and North Carolina, and already femaleskewed populations are likely to become further skewed with as little as $1^{\circ} \mathrm{C}$ warming. These will suffer 
extreme mortality if warming exceeds $3^{\circ} \mathrm{C}$ (Hays 2008). This indicator would identify a critical threshold for sex ratios in terms of population viability.

\section{Terrestrial mammals}

Indicator 12: Caribou/reindeer calf production and survival

Caribou Rangifer tarandus migrate between seasonal ranges and their migration to calving areas coincides with the emergence of their plant forage, which is essential for the newborn calves (Post \& Forchhammer 2007). Calf production and survival may therefore be good indicators of the effect of temperature increases, since higher temperatures appear to be correlated with a mismatch between the timing of the peaks in calf production and forage availability (Post \& Forchhammer 2007). This mismatch probably results in reduced foraging success of the lactating females with negative impacts on newborn calves (Post \& Forchhammer 2007). Relationships have been observed in several caribou populations between reproductive success parameters, the timing of life-history events, and winter and summer climate, spring temperatures, the North Atlantic Oscillation (NAO) and the Arctic Oscillation (AO) (e.g. Post \& Klein 1999, Post \& Stenseth 1999, Aanes et al. 2000, Post et al. 2001, Forchhammer et al. 2002, Chan et al. 2005, Post \& Forchhammer 2007). This indicator would illustrate the effects of climate change on several ecosystems (high Arctic islands, boreal forest and tundra) within the range of caribou/reindeer populations. The status of caribou populations is also very important for Arctic and subarctic ecosystem functioning, and is of socio-economic value.

Indicator 13: Population sizes and geographic ranges of large herbivorous mammals

Declines in several species of large mammals in Africa have been related to reduced precipitation, which in turn could be related to climate change (Mduma et al. 1999, Ogutu \& Owen-Smith 2003, Owen-Smith et al. 2005). Lower precipitation reduces growth of forage plants and may increase predation risk (Ogutu \& Owen-Smith 2003, Musiega \& Kazadi 2004). The extent to which large migratory herbivorous mammals in Africa will adapt to the effects of climate change on their habitats will greatly depend on their ability to change their distribution and movement patterns to match changes in the available resources. However, due to intense land transformation, the connectivity between natural seasonal ranges of migratory species has been very much reduced. There is currently little evidence that mammals' ranges in Africa have changed in response to climate change (Owen-Smith et al. 2005). However, the effects of climate change on regional climate in Africa are not well documented (IPCC 2007). There is also uncertainty regarding predictions of future African climate with climate change (IPCC 2007). Nevertheless, temperatures are set to increase and this may exacerbate the impacts of droughts (IPCC 2007). Modelling studies indicate that substantial range shifts are likely to occur as a result of drier conditions, and these could lead to species declines or even extinctions, mainly due to a reduction in the habitat available (caused by landtransformation and climate change) (Erasmus et al. 2002, Thuiller et al. 2006). Drought changes food resources and causes mass mortality with immediate effect on population size (Erasmus et al. 2002, Thuiller et al. 2006). Range shifts, on the other hand, cannot be clearly linked to population dynamics. However, it has been shown that a reduction in the habitat available (caused by land-transformation) and consequent changes in movements have led to a $75 \%$ decline in a population of wildebeest (Homewood et al. 2001). Species that could be used to develop this indicator are either listed on CMS Appendices (e.g. African elephant Loxodonta africana) or would be representative of large mammals in general, where population sizes are sufficient to allow an indicator to be developed (e.g. wildebeest Connochnetes taurinus and Thompson's gazelle Gazella thomsonii). In addition these species are of major economic and ecological importance with a high public profile throughout the world; for example, the wildebeest is a symbol of the Serengeti-Mara ecosystem.

\section{Indicator 14: Population size of saiga antelope}

The modelled population dynamics of saiga antelope Saiga tatarica, a species that inhabits the plains of Kazakhstan, Mongolia, Russia, Turkmenistan and Uzbekistan, are sensitive to assumptions about the probability of a drought or harsh winter occurrence (Milner-Gulland 1994). These conditions have, in the past, caused mass mortality in saiga populations, due to animals being unable to obtain sufficient forage. However, more research is needed to establish a link between population dynamics and climate change. The region in central Asia inhabited by the saiga is mostly semi-arid and arid (IPCC 2007), with all areas experiencing wide fluctuations in rainfall. Their native plants and animals are adapted to coping with sequences of extreme climatic conditions. Central 
Asian climate is likely to become drier and hotter (IPCC 2007). Climate-induced mortality is negated somewhat by migration and a high reproductive rate. Nevertheless, if more droughts were to occur it is very likely that a population impact caused by mass mortality would be evident (Milner-Gulland 1994).

\section{Bats}

Indicator 15: Abundance of bats at 'underground' hibernation sites in Europe

Hibernation is a crucial strategy for almost all northern temperate bats to survive periods of insect shortage, even where there is migration between summer and winter quarters (Ransome 1990). Changes in air temperature in and around hibernation sites will affect suitability of sites for different species (Ransome 1990). Higher temperature and other climate changes will affect hibernation behaviour and may have effects on migration and over-wintering survival (Speakman \& Thomas 2003). While the requirements for hibernation can be very precise, temperature and humidity are almost exclusively the natural factors controlling hibernation (Speakman \& Thomas 2003). Changes of temperature as a result of climate change are expected to influence regional species composition, impact on hibernation behaviour, and in turn affect productivity and survival (Robinson et al. 2005). In addition to demonstrating change in population size, this indicator would illustrate changes in distribution and species composition. Bats receive a mixed public perception, but there is a lot of public support for, and interest in, their conservation.

Indicator 16: Populations of straw-coloured fruit bat in Africa

The straw-coloured fruit bat Eidolon hevlum relies on a succession of flowering and fruiting food plants, partly acquired through the migratory or nomadic behaviour of the bat (see Richter \& Cumming 2008). Changes in temperature and rainfall patterns, which influence seasonal flowering and fruiting of food trees, correlate with foraging behaviour (including migratory behaviour) and are likely to affect colony structure and formation, with consequent effects on productivity and juvenile survival (Richter \& Cumming 2008). There is some existing evidence of changes in distribution and behaviour in similar species of fruit bat within Australia (Hughes 2003), and also evidence of stress and mortality induced by excessive temperatures - a suggested likely impact of climate change (Welbergen et al. 2008). Bumrungsri (2002) has related effects of extreme weather events to the breeding success of fruit bats in south-east Asia. The indicator will identify changes in populations and behaviour that can be used to assess longer-term impacts on the species.

Indicator 17: Populations of Mexican free-tailed bats

The Mexican free-tailed bat Tadarida brasiliensis, which occurs in large concentrations, relies on high densities of prey insects, including those concentrated in insect mass-movements through the region of the roost (a colony of 20 million bats eats ca.125 t of insects per night) (Wilkins 1989, Bumrungsri 2002). Changes in temperature and rainfall patterns (plus the increased intensity of extreme weather events) are likely to affect the availability of insect prey (Scheel et al. 1996). While the prey resources may shift, the cave roost sites cannot. As such, cave roosting bats such the Mexican free-tailed bat are particularly likely to be impacted by climate change (Scheel et al. 1996). As a representative for cave-dwelling bats in the Tropics, this single species indicator will relate the impact of changes in temperature and other regional weather patterns to population size at maternity roost sites. This species is selected because there is a large and longterm body of population data for this species and modern technology has allowed for the population size of this species to be estimated with an acceptable level of precision (O'Shea \& Bogan 2003).

\section{DISCUSSION}

\section{Choosing and developing indicators for endangered species}

Whilst an attempt was made to select indicators that present the clearest signal of the negative impacts of climate change on migratory species, it is likely that these indicators will also be subject to other strong influences. In addition it is clear from Table 2 that very few indicators scored highly for their specificity and theoretical basis. Species on the CMS Appendices are particularly challenging for the development of reliable indicators. Besides the fact that many CMS species do not have good quality long-term time series of data, most are endangered, have small population sizes and are threatened by other strong human pressures, resulting in low specificity of potential indicators. This will be a problem across endangered species in general where the data needed for an indicator might not be available and developing indicators specific to one single pressure might not be the best use of 
resources. The effects of climate change on species result from complex interactions between global climate, regional climate, local atmospheric/ocean processes, and other anthropogenic pressures such as fishing, contaminants and habitat loss. In addition, ecological mechanisms influencing the populations, such as density-dependent factors and species interactions, may act in consort with, synergistically with or in opposition to effects of climate change. Physical, anthropogenic and ecological processes should be considered in conjunction if we are to understand the causal mechanisms that control population dynamics (Stenseth et al. 2002, Mori \& Butterworth 2006). For any population, the interactions of all these pressures represent one state to which the population needs to adapt. If one is to have any chance of adequately conserving species/populations, then consideration should be given to all the pressures together. Therefore, where possible, indicators should be complemented by analyses to identify the contribution of climate change, over and above other influences. It is also important that, where there is additional information that provides support for an indicator, this is presented with the indicator. This may include distributional change or phenological indicators which reflect climate change, but where the impact is currently unclear. In addition, remote sensing information provides an extremely powerful resource for putting an indicator in context. This has the potential for improving our understanding of how climate change processes affect populations and as a more general tool for explaining what is happening to a wider audience.

\section{Representativeness of the proposed indicator suite}

Whilst the scope of this exercise was global and an attempt was made to consider all migratory wildlife, the choice of indicators will, to some degree, reflect the knowledge of the experts who have contributed to this selection and will be driven by their understanding of climate change impacts. We believe that the numbers of indicators for birds, turtles, fish, marine mammals and terrestrial mammals presented here are broadly in the proportion that we would expect considering our current understanding of the detrimental impacts of climate change on migratory species. Excluded from the indicator suite are groups such as plankton, crustaceans, cephalopods, amphibians and insects, although these contain few species regarded as migratory according to the CMS.

In terms of habitat coverage, the literature suggests that the impacts of climate change on migratory species are likely to be most pronounced in 5 principal habitats: marine and coastal, freshwater, tundra, mon- tane and arid terrestrial (e.g. IPCC 2007). These habitats are all represented in the proposed suite, although there is currently only one indicator for freshwater and one for montane habitats (see Table 2). In relation to geographical coverage, there is low representation for terrestrial species in Asia, South America and Australia and for marine species in the Pacific and Indian Oceans.

\section{Baseline recommendations}

As recommended by Rice \& Rochet (2005), in order to maintain a scientific basis, advance testing of individual indicator performance should ideally be undertaken before use of an indicator is implemented. Each indicator suggested here would need to be agreed and developed by those expert groups that hold the time series of data in conjunction with any bodies that are responsible for monitoring/responding to impacts of climate change. It is possible that for a small number of the indicators presented here, such as the indicators for populations of trans-Saharan migrant birds and polar bear body condition and survival, it would be relatively straightforward to implement an indicator of the impacts of climate change, given the existence of wellestablished standardised monitoring protocols and if support was obtained from the appropriate data providers. In addition, the methods for constructing indicators from such data are already well developed for other purposes. However, most indicators proposed here require additional data collection and or collation and, and in many cases, would require data collation and some development of novel methods for producing trends and constructing indicators. In the development of all indicators, it is essential to consider how the outputs will relate to conservation objectives and how a system of alerts and triggers for action could be implemented. Evaluating these indicators from a policyneeds perspective should now be a priority.

Acknowledgements. We thank the participants in a workshop held in Norwich, December 2007, during which the indicator suite was devised, who gave their time freely to contribute ideas and comments. This includes R. Brett (Flora and Fauna International), S. Butchart (Birdlife International), S. Delany (Wetlands International), S. Dereliev (African-Eurasian Waterbird Agreement), W. Foden (International Union for Conservation of Nature), C. Francis (Canadian Wildlife Service), J. Gill (University of East Anglia), R. Gregory \& J. O'Sullivan (Royal Society for the Protection of Birds), J. Harwood (Sea Mammal Research Unit), K. Haysom (Bat Conservation Trust), B. Hughes (Wildfowl and Wetlands Trust), S. Jennings (Centre for Environment, Fisheries \& Aquaculture Science), I. Maclean, D. Noble \& M. Rehfisch (British Trust for Ornithology), I. Mitchell, D. Stroud \& M. Tasker (Joint Nature Conservation Committee), J.-P. Moussus (Muséum National d'His- 
toire Naturelle, Paris), D. Pomeroy (Makerere University, Uganda) and S. Willis (Durham University). We also thank a number of other people who were consulted by email (A. Derocher, E. Post, R. Leaper, J. Forcada and E. J. Milner-Gulland). We are grateful to the project's Steering Group for all the help and advice they gave throughout: M. Barbieri (CMS), S. Cunningham (Defra), K. Dickinson (JNCC), K. Humphrey (Defra), D. Procter (JNCC), M. Stevenson (Defra) and A. Williams (Defra). Thanks also to M. Andrews. This project was funded by the UK Department for Environment, Food and Rural Affairs.

\section{LITERATURE CITED}

Aanes R, Sæther BE, Øritsland NA (2000) Fluctuations of an introduced population of Svalbard reindeer: the effects of density dependence and climatic variation. Ecography 23: 437-443

Austin G, Rehfisch MM (2005) Shifting non-breeding distributions of migratory fauna in relation to climate change. Glob Change Biol 11:31-38

Beale CM, Dodd S, Peace-Higgins JW (2006) Wader recruitment indices suggest nesting success is temperaturedependent in dunlins Calidris alpina. Ibis 148:405-410

Beaugrand G, Reid P (2003) Long-term changes in phytoplankton, zooplankton and salmon related to climate. Glob Change Biol 9:801-817

Berry PM, Vanhinsberg D, Viles HA, Harrison PA and others (2001) Impacts on terrestrial environments. In: Harrison PA, Berry PM, Dawson TP (eds) Climate change and nature conservation in Britain and Ireland: modelling natural resource responses to climate change (the MONARCH project). UKCIP Technical report, Oxford, $\mathrm{p} 43-50$

Both C, Visser ME (2001) Adjustment to climate change is constrained by arrival date in a long distance migrant bird. Nature 411:296-298

Bumrungsri S (2002) The foraging ecology of the short-nosed fruit bat, Cynopterus brachyotis (Muller, 1838), in lowland dry evergreen rain forest, Southeast Thailand. $\mathrm{PhD}$ dissertation, University of Aberdeen

Chan KS, Mysterud A, Øritsland NA, Severinsen T, Stenseth NC (2005) Continuous and discrete extreme climatic events affecting the dynamics of a high-arctic reindeer population. Oecologia 145:556-563

Clark JA, Robinson RA, Clark NA, Atkinson PW (2004) Using the proportion of juvenile waders in catches to measure recruitment. Wader Study Group Bull 104:51-55

Cooke J, Rowntree V, Payne R (2003) Analysis of inter-annual variation in reproductive success of South Atlantic right whales Eubalaena australis from photo-identifications of calving females observed off Península Valdés, Argentina, during 1971-2000. Presented to IWC Scientific Committee, Berlin, June 2003

Crick HQP (1999) Small bird population changes. In: Cannell MGR, Palutikof JP, Sparks TH (eds) Indicators of climate change in the UK. DETR \& NERC, London, p 64-67

Crick HQP, Sparks TH (1999) Climate related to egg-laying trends. Nature 399:423-424

Croxall JP, Trathan PN, Murphy EJ (2002) Environmental change and Antarctic seabird populations. Science 2970: $1510-1514$

Crozier L, Zabel RW (2006) Climate impacts at multiple scales: evidence for differential population responses in juvenile Chinook salmon. J Anim Ecol 75:1100-1109

Donato M (2002) A statistical model for estimating stream temperatures in the salmon and clearwater river basins,
Central Idaho. US Department of the Interior, US Geological Survey. Idaho Department of Environmental Quality, Boise, ID. http://id.water.usgs.gov/PDF/wri024195/ index.html

> Dulvy NK, Rogers SI, Jennings S, Stetzenmiller V, Dye SR, Skjoldal HR (2008) Climate change and deepening of the North Sea fish assemblage: a biotic indicator of warming seas. J Appl Ecol 45:1029-1039

Erasmus BFN, Van Jaarsweld AS, Chown SL (2002) Vulnerability of South African animal taxa to climate change. Glob Change Biol 8:679-693

> Ferguson SH, Stirling I, Cloughlin PM (2005) Climate change and ringed seal Phoca hispida recruitment in western Hudson Bay. Mar Mamm Sci 21:121-135

Fish MR, Côté IM, Gill JA, Jones AP, Renshoff S, Watkinson AR (2005) Predicting the impact of sea-level rise on Caribbean sea turtle nesting habitat. Conserv Biol 19:482-491

> Forcada J, Trathan P, Reid K, Murray E (2005) The effects of global climate variability in pup production of Antarctic fur seals. Ecology 86:2408-2417

Forchhammer MC, Post E, Stenseth NC, Boertmann DM (2002) Long-term responses in arctic ungulate dynamics to changes in climatic and trophic processes. Popul Ecol 44: 113-120

> Frederiksen M, Edwards M, Mavor AR, Wanless S (2007) Regional and annual variation in black-legged kittiwake breeding productivity is related to sea surface temperature. Mar Ecol Prog Ser 350:137-143

> Godfrey MH, Barreto R, Mrosovsky N (1996) Estimating past and present sex ratios of sea turtles in Suriname. Can J Zool 74:267-277

Greene CH, Pershing AJ (2004) Climate and the conservation biology of North Atlantic right whales: the right whale at the wrong time? Frontiers Ecol Environ Sci 2:29-34

Gregory RD, Noble DG, Custance J (2004) The state of play of farmland birds: population trends and conservation status of lowland farmland birds in the United Kingdom. Ibis 146:1-13

> Guinet C, Jouventin P, Georges JY (1994) Long term population changes of fur seals Arctocephalus gazella and Arctocephalus tropicalis on subantarctic (Crozet) and subtropical (St. Paul and Amsterdam) islands and their possible relationship to El Niño Southern Oscillation. Antarct Sci 6: 473-478

Hare SR, Francis RC (1994) Climate change and salmon production in the northeast Pacific Ocean. In: Beamish RJ (ed) Climate change and northern fish populations. Can Spec Publ Fish Aquat Sci 121:357-372

Härkönen T, Stenman O, Jussi M, Jussi I, Sagitov R, Vereukin M (1998) Population size and distribution of the Baltic ringed seal (Phoca hispida botnica). In: Heide-Jörgensen M, Lydersen C (eds) Ringed seals in the North Atlantic. University of Bergen, Bergen

> Harris MP, Wanless S (1990) Breeding success of British kittiwakes Rissa tridactyla in 1986-88: Evidence for changing conditions in the northern North Sea. J Appl Ecol 27: $172-187$

Harrison P (ed) (2006) GEO Yearbook 2006: An overview of our changing environment. UNEP, Nairobi

Hawkes LA, Broderick AC, Godfrey MH, Godley BJ (2007) Investigating the potential impacts of climate change on a marine turtle population. Glob Change Biol 13:923-932

Hays GC (2008) Sea turtles: a review of some key recent discoveries and remaining questions. J Exp Mar Biol Ecol 356:1-7

- Hays GC, Broderick AC, Glen F, Godley BJ (2003) Climate change and sea turtles: a 150-year reconstruction of incu- 
bation temperatures at a major marine turtle rookery. Glob Change Biol 9:642-646

Homewood K, Lambin E, Coast E, Kariuki A and others (2001) Long-term changes in Serengeti-Mara wildebeest and land cover: pastoralism, population, or policies? Proc Natl Acad Sci USA 98:12544-12549

> Houghton JDR, Myers AE, Lloyd C, King RS, Isaacs C, Hays GC (2007) Protracted rainfall decreases temperature within leatherback turtle Dermochelys coriacea clutches in Grenada, West Indies: Ecological implications for a species displaying temperature dependent sex determination. J Exp Mar Biol Ecol 345:71-77

Hughes L (2003) Climate change and Australia: trends, projections and impacts. Aust Ecol 28:423-443

Hyatt KD, Stockwell MM, Rankin DP (2003) Impact and adaptation responses of Okanagan river Sockeye salmon (Oncorhynchus nerka) to climate variation and change effects during freshwater migration: stock restoration and fisheries management implications. Can Water Resour J 28:689-713

IPCC (2007) Climate change 2007: the physical science basis. In: Solomon S, Qin D, Manning M, Chen Z and others (eds) Contribution of Working Group I to the Fourth Assessment. Report of the Intergovernmental Panel on Climate Change. Cambridge University Press, Cambridge

Lea MA, Guinet C, Cherel Y, Duhamel G, Dubroca L, Pruvost P, Hindell M (2006) Impacts of climatic anomalies on provisioning strategies of a Southern Ocean predator. Mar Ecol Prog Ser 310:77-94

Leaper R, Cooke J, Trathan P, Reid K, Rowntree V, Payne R (2006) Global climate drives southern right whale (Eubalaena australis) population dynamics. Biol Lett 2:289-292

Learmonth J, MacLeod CD, Santos MB, Pierce GJ, Crick HQP, Robinson R (2006) Potential effects of climate change on marine mammals. Oceanog Mar Biol Annu Rev 44:431-464

Lehikoinen E, Sparks TH, Zalakevicius M (2004) Arrival and departure dates. Adv Ecol Res 35:1-31

Maclean IMD, Austin GE, Rehfisch MM, Crowe O and others (2008) Climate change causes rapid changes in the distribution and site abundance of birds in winter. Glob Change Biol 14:2489-2500

MacLeod CD, Bannon SM, Pierce GJ, Schweder C, Learmonth JA, Herman JS, Reid RJ (2005) Climate change and the cetacean community of north-west Scotland. Biol Conserv 124:477-483

Mantua NJ, Hare SR, Zhang Y, Wallace JM, Francis RC (1997) A Pacific interdecadal climate oscillation with impacts on salmon production. Bull Am Meteorol Soc 78: 1069-1079

Mduma SAR, Sinclair ARE, Hilborn R (1999) Food regulates the Serengeti wildebeest: a 40-year record. J Anim Ecol 68:1101-1122

Milner-Gulland EJ (1994) Population model for the management of the Saiga Antelope. J Appl Ecol 31:25-39

Mori M, Butterworth DS (2006) A first step towards modelling the krill-predator dynamics of the Antarctic ecosystem. CCAMLR Science 13:217-277

Moy CM, Seltzer GO, Rodbell DT, Anderson DM (2002) Variability of El Niño /Southern Oscillation activity at millennial timescales during the Holocene epoch. Nature 420: 162-165

> Mueter FJ, Peterman RM, Pyper BJ (2002) Opposite effects of ocean temperature on survival rates of 120 stocks of Pacific salmon (Oncorhynchus spp.) in northern and southern areas. Can J Fish Aquat Sci 59:456-463
Murphy EJ, Trathan PN, Watkins JL, Reid K and others (2007) Climatically driven fluctuations in Southern Ocean ecosystems. Proc R Soc Lond B Biol Sci 274:3057-3067

Musiega DE, Kazadi SN (2004) Simulating the East African wildebeest migration patterns using GIS and remote sensing. Afr J Ecol 42:355-362

Newson SE, Dulvy N, Hays GC, Houghton JDR and others (2008) Indicators of the impact of climate change on migratory species. BTO Research Report 495, British Trust for Ornithology, Thetford

Ogutu JO, Owen-Smith N (2003) ENSO, rainfall and temperature influences on extreme population declines among African savannah ungulates. Ecol Lett 6:1-8

O'Shea TJ, Bogan MA (eds) (2003) Monitoring trends in bat populations of the United States and territories: problems and perspectives. U.S. Geographical Survey, Biological Resources Discipline, Information and Technology Report 2003-0003. U.S. Geological Survey, Fort Collins, CO

Owen-Smith N, Mason DR, Ogutu JO (2005) Correlates of survival rates for 10 African ungulate populations: density, rainfall and predation. J Anim Ecol 74:774-788

Pauly D, Watson R (2005) Background and interpretation of the 'Marine Trophic Index' as a measure of biodiversity. Phil Trans R Soc Lond B 360:415-423

Perry AL, Low PJ, Ellis JR, Reynolds JD (2005) Climate change and distribution shifts in marine species. Science 308:1912-1913

Pierce GJ, Boyle PR (2003) Empirical modelling of interannual trends in abundance of squid (Loligo forbesi) in Scottish waters. Fish Res 59:305-326

Post E, Forchhammer MC (2007) Climate change reduces reproductive success of an Arctic herbivore through trophic mismatch. Phil Trans R Soc Lond B Biol Sci 1098:1-7

Post E, Klein DR (1999) Caribou calf production and seasonal range quality during a population decline. J Wildl Manag 63:335-345

Post E, Stenseth NC (1999) Climatic variability, plant phenology, and northern ungulates. Ecology 80:1322-1339

> Post E, Forchhammer MC, Stenseth NC, Callaghan TV (2001) The timing of life-history events in a changing climate. Proc R Soc Lond B Biol Sci 268:15-23

Ransome R (1990) The natural history of hibernating bats. Christopher Helm, London

Regehr EV, Amstrup SC, Stirling I (2006) Polar bear population status in the southern Beaufort Sea. US Geological Survey Open-File Report 2006-1337, Reston, VA

> Regehr EV, Lunn NJ, Amstrup SC, Stirling I (2007a) Effects of earlier sea ice breakup on survival and population size of polar bears in Western Hudson Bay. J Wildl Manag 71: 2673-2683

Regehr EV, Lunn NJ, Amstrup SC, Stirling I (2007b) Supplemental materials for the analysis of capture-recapture data for polar bears in western Hudson Bay, Canada, 1984-2004. U.S. Geological Survey Data Series 304, Reston, VA

> Reid K, Arnould JPY (1996) The diet of Antarctic fur seals Arctocephalus gazelle during the breeding season at South Georgia. Polar Biol 16:105-114

> Reid K, Croxall JP, Briggs DR, Murphy EJ (2005) Antarctic ecosystem monitoring: quantifying the response of ecosystem indicators to variability in Antarctic krill. ICES J Mar Sci 62:366-373

> Rice J (2003) Environmental health indicators. Ocean Coast Manag 46:235-259

Rice J, Rochet MJ (2005) A framework for selecting a suite of indicators for fisheries management. ICES J Mar Sci 62: $516-527$ 
Richter HV, Cumming GS (2008) First application of satellite telemetry to track African straw-coloured fruit bat migration. J Zool (Lond) 275:172-176

Robinson RA, Learmouth JA, Hutson AM, MacLeod CD and others (2005) Climate change and migratory species. BTO Research Report No. 414. Defra, London

Robinson RA, Crick HQP, Learmonth JA, Maclean IMD and others (2009) Travelling through a warming world: climate change and migratory species. Endang Species Res 7: 87-99

Rode KD, Amstrup SC, Regehr EV (2007) Polar bears in the Southern Beaufort Sea III: Stature, mass, and cub recruitment in relationship to time and sea ice extent between 1982 and 2006. U.S. Geological Survey Report to U.S. Fish and Wildlife Service. Anchorage, AK

Sanderson FJ, Donald PF, Burfield IJ, van Bommel FPJ (2006) Long-term population declines in Afro-Palearctic migrant birds. Biol Conserv 131:93-105

Scheel D, Vincent TLS, Cameron GN (1996) Global warming and the species richness of bats in Texas. Conserv Biol 10: $452-464$

Schekkerman H, Van Roomen MWJ, Underhill LG (1998) Growth, behaviour of broods and weather-related variation in productivity of curlew sandpipers Calidris ferruginea. Ardea 86:153-168

Sims DW, Genner MJ, Southward AJ, Hawkins SJ (2001) Timing of squid migration reflects North Atlantic climate variability. Proc R Soc Lond B Biol Sci 268:2607-2611

Smith TG, Harwood LA (2001) Observations of neonate ringed seals, Phoca hispida, after early break-up of the sea ice in Prince Albert Sound, Northwest Territories, Canada, spring 1998. Polar Biol 24:215-219

Soto KH, Trites AW, Arias-Schreiber M (2004) The effects of prey availability on pup mortality and the timing of birth of South American sea lions Otaria flavescens in Peru. J Zool (Lond) 264:419-428

Sparks TH, Huber K, Bland RL, Crick HQP and others (2007) How consistent are trends in arrival (and departure) dates of migrant birds in the UK? J Ornithol 148:503-511

Speakman JR, Thomas DW (2003) Physiological ecology and energetics of bats. In: Kunz TH, Fenton MB (eds) Bat ecology. University of Chicago Press, Chicago, IL, p $430-490$

Editorial responsibility: Brendan Godley,

University of Exeter, Cornwall Campus, UK
Stenseth NC, Mysterud A, Ottersen G, Hurrell JW, Chan KS, Lima M (2002) Ecological effects of climate fluctuations. Science 297:1292-1296

Stern N (2007) The economics of climate change: The Stern Review. Cambridge University Press, Cambridge

> Stirling I (2005) Reproductive rates of ringed seals and survival of pups in Northwestern Hudson Bay, Canada, 1991-2000. Polar Biol 28:381-387

Stirling I, Lunn NJ, Iacozza J (1999) Long-term trends in the population ecology of polar bears in western Hudson Bay in relation to climate change. Arctic 52:294-306

Thuiller W, Broennimann O, Hughes G, Alkemade JRM, Midgley GF, Corsi F (2006) Vulnerability of African mammals to anthropogenic climate change under conservative land transformation assumptions. Glob Change Biol 12:424-440

Timmermann A, Oberhuber J, Bacher A, Esch M, Latif M, Roeckner E (1999) Increased El Niño frequency in a climate model forced by future greenhouse warming. Nature 398:694-697

> Trathan PN, Murphy EJ (2002) Sea surface temperature anomalies near South Georgia: relationships with the pacific El Niño regions. J Geophys Res 108:8075

- Trathan PN, Brierley AS, Brandon MA, Bone DG and others (2003) Oceanographic variability and changes in Antarctic krill Euphausia superba abundance at South Georgia. Fish Oceanogr 12:569-583

Tulp I, Schekkerman H (2008) Has prey availability for Arctic birds advanced with climate change? Hindcasting the abundance of tundra arthropods using weather and seasonal variations. Arctic 61:48-60

Welbergen JA, Klose SM, Markus N, Eby P (2008) Climate change and the effects of temperature extremes on Australian flying-foxes. Proc R Soc Lond B Biol Sci 275:419-425

Wilkins KT (1989) Tadarida brasiliensis. Mamm Species 331:1-10

> Wilson PR, Ainley DG, Nur N, Jacobs SS, Barton KJ, Ballard G, Comiso JC (2001) Adélie penguin population changes in the pacific sector of Antarctica: relation to sea-ice extent and the Antarctic Circumpolar Current. Mar Ecol Prog Ser 213:301-309

> Zheng X, Pierce GJ, Reid D (2001) Spatial patterns of whiting abundance in Scottish waters and relationships with environmental variables. Fish Res 50:259-270

Submitted: August 1, 2008; Accepted: October 10, 2008

Proofs received from author(s): November 20, 2008 